\title{
E-learning within the Field of Andragogy
}

\author{
https://doi.org/10.3991/ijet.v14i09.10020 \\ Olga V. Galustyan ( $\left.{ }^{\varpi}\right)$ \\ Southern Federal University, Rostov-on-Don, Russia \\ olga.galustyan@gmail.com \\ Yana V. Borovikova \\ Institute of Social Education, Voronezh, Russia \\ Nadezhda P. Polivaeva \\ Voronezh Institute of the Federal Penitentiary Service of Russia, Voronezh, Russia \\ Bakhtiyor R. Kodirov \\ Voronezh State Technical University, Borisoglebsk, Russia \\ Galina P. Zhirkova \\ St. Petersburg National Research University of Information Technology, St. Petersburg, Russia
}

\begin{abstract}
The article analyzes a new education paradigm based on the concept of e-learning, which relates to the ideas of andragogy. The article deals with the openness of education for each individual, that is confirmed by the fact that each individual is provided with the conditions for free development of his/her educational, intellectual and activity opportunities throughout his/her life. The article presents the main differences between the traditional education and e-learning. The most appropriate andragogical platform means continuous, student-centered adult education, there are significant changes in the purpose and the content of teaching, social roles, forms and nature of communication between the teacher and the student, based on e-learning.
\end{abstract}

Keywords-E-learning, andragogy, open education, continuing education, activity opportunities

\section{$1 \quad$ Introduction}

Mankind has accumulated a number of global political, economic, environmental, geopolitical, information problems, the solution of which requires a special degree of openness, mutual understanding and purposeful interaction of different countries and people by the 21 st century $[12,17,18,27,29]$. This approach becomes more understandable as it takes into account the fact that unpredictability and remoteness of consequences, interdependence and internal inconsistency. Inclusion of individual and the whole of humanity as a whole in the content and solution of this "problem field" are typical for global problems $[5,11,28]$. Growing processes of globalization, integra- 
tion of the economic and cultural structures of different countries and people necessitate the promotion of the ideal of open society. The realization of the idea of openness of public development generates the need to form an open educational system that is able to respond quickly to changing social and economic realities and the corresponding individual and group educational needs and demands. E learning is based on ideas of ideological and methodological pluralism, openness and continuity of the process of cognition, focus on humanistic and democratic values [13, 15, 25].

Different interpretations of e-learning lead to the fact that today there are several concepts of e-learning. Each of these concepts has its historical roots in the distant past and has a concrete embodiment in modern educational institutions which are open to world culture, society and people $[4,21]$.

Modern stage of civilization development is associated with the formation of the post-industrial, information society, for which qualitative changes are characteristic in various spheres of public life, including education. These changes are because of that fact that today there is a sharp increase in the social significance of relevant information, growth of technological opportunities for obtaining, transferring, storing and using information in ever increasing volumes. Currently, leadership belongs to information and telecommunication technologies. Dominants in the economic development of society are the industries associated with the production of information, knowledge, information services.

Thus, growing integration and information processes lead to openness and information transparency of modern society. It should be noted that e-learning is born by modern society not only by the benefit associated with the possibility of integrating the resources of individual countries, creating economically efficient transnational corporations, leveling the living conditions of different peoples, relieving international tension and confrontation, but also by many economic, political, and moral problems.

\section{Methodology}

Researchers [1,3] consider that the openness of society increases, its stability against the external destructive influences' decreases, which can be directed at the destruction of national culture, formation of economic and political dependence. Growth of openness and dynamism in social development is steadily leading to the fact that the society is becoming less predictable, the degree of its uncertainty is increasing, its social stability is declining. There are profound changes in the social status of a person in modern society, other values are acquired by such concepts as freedom, responsibility, self-realization. Multifaceted social creativity is developing, reflecting the process of creating a new social space, in which educational processes unfold $[7,10]$. Comprehension and transformation of these processes is associated with the global changes in education. That means that a new concept is emerging along with the traditional notion of education as a system of knowledge and skills that needs new formation of personality, his /her goals, relationships, and motivation. 
A new paradigm of education emerges in connection with the change in social orders of society, which are based on the concept of personal and practical-oriented learning, and, in the social plan, approaches the ideals of e-learning.

E-learning is manifested in its high dynamism, predominance of trend of intensive social interactions, social partnership, focus on the positive development of each individual and society as a whole on the basis of individual initiatives. New social realities require openness to the future, mobility and variability of experience within the limits of one generation's life from the education institutions. E-learning is closely connected with the andragogy (education of adults). Andragogists in their turn are engaged in e-learning of adults. The flowering of andragogy can undoubtedly be attributed to the second half of the twentieth century. It is associated with the name of the outstanding American practice and theorist of adult education M. Knowles (1970) [16], who called andragogy the science and art of adult learning, highlighting the following basic principles:

- Adult education should be focused on solving a specific problem

- Adult education should consider and rely on the experience of the teachers

- Experience and knowledge gained because of training should be significant for the teacher

- Teacher should be able to check and analyze teaching material

- Learning objectives should be formulated jointly by the teacher and the student

- Teacher should receive feedback concerning the progress

The main differences between traditional learning and e learning that there are significant changes in the purpose and content of learning, social roles, forms and nature of communication between the teacher and the student.

Continuity of education, high flexibility, through which an individual vector of growth and development of each student should be provided. The following basic views underlie the modern concept of e-learning such as purposefulness, cyclicity, continuity of the received knowledge, multistage, variability, system, individualization, flexibility, modularity, accessibility. Open education based on use of new information distance technologies in the organization of the educational process is designed to solve the problems of practical implementation of e-learning.

The traditions of adult education, institutions of functioning, foundations of scientific approaches are studied by many scientists and practitioners. Among them are [2, $8,9,14]$, who contributed to the spread of both the term "andragogy" and the new approach to adult learning. Further increase in the role of continuing education, education of adults, which are typical both for many countries, associated with global changes and the transition from a postindustrial to an information society, presuppose, as the leading type of activity, the work of a person with information, as such activity is a kind of education.

Adult education is an important part of the system of e-learning, encompassing all educational activities in relation to adults. According to the idea of e-learning within the field of andragogy, every person has the right to education in every period of his/her life, and the state, society has to provide him/her with the various forms of education, to help and to care about them. The concept of e-learning is actively devel- 
oping in all countries of the European region. E-learning within the field of andragogy is connected with the openness of education for each individual which is most fully realized within system of e-learning. E-learning provides every individual with the conditions for free development of his/her educational, intellectual and activity opportunities throughout his/her life.

E-learning within the field of andragogy should be regarded as a factor of development and self-realization of individuals who are the main resource of dynamically developing post-industrial society. At the same time, e-learning within the field of andragogy is treated not as an administrative mix of different types of educational institutions in an integrated system, but as a thoughtful variable system of providing educational services that allows individuals to use them in accordance with his/her personal needs and demands at different periods of his/her life [22, 24, 26].

The concept of e-learning within the field of andragogy is based on the ideas of a specific social and cultural phenomenon and those organizational and pedagogical principles that underlie the education systems $[6,19,23]$. It is necessary to provide the person with opportunities to solve the problems facing the society:

- To learn to know, i.e. to provide necessary tools for understanding what is happening in the world;

- To learn to do in order to produce necessary changes in the environment;

- To learn modern life in order to take part in all kinds of human activities and to cooperate with the other people.

All these four "pillars" of cognition form a single whole, since there are numerous connections, transitions and exchanges between them.

\section{$3 \quad$ Materials and Methods}

Experimental work took place in 2017-2018 at universities (Southern Federal University, Institute of Social Education) of Rostov-on-Don and Voronezh within the training courses on the development of ICT competence. 158 teachers participated in the study. Respondents were from 35 to 50 years of age. The experimental group consisted of 79 teachers. The content part of the experiment was represented by the course "Teachers' Activity in Creating Electronic Educational Environment". The control group included 78 teachers. They were trained within the traditional face-toface educational system without e-learning using ICT in the classroom. The experimental group was trained using e-learning. Digital services were used to provide computerized visualization of information and interactive interaction of participants within the learning process. The structure of the content of services was determined by their functionality.

Such technological requirements for the development of digital services were kept in the experimental group:

- Content files were located outside of the compiled executable file to ensure that the content can be updated 
- Intuitive graphical interface with a frame presentation of the content to ensure their availability was used

- Multimedia technology, hypertext and hypermedia for computer visualization of information were used

All the developed services gave the possibility of introducing a remote form of contacting teachers and participants of the courses. Digital services offered group and individual forms of communication within the course.

\section{$4 \quad$ Results}

We followed the pedagogical conditions in order to implement the realization of the experimental work. It was necessary:

- To ensure freedom of choice for each person of his/her own "trajectory" corresponding to the world level of social, cultural, intellectual development

- To create e-learning environment that promotes the cultural, creative flourishing of the individuality of each participant

- To determine the methods and technologies of training in order to form the trajectory of professional activity

- To create conditions for an adequate assessment of the personal and professional development

Initial study was conducted to identify the initial level of ICT competency in the experimental and control groups at the beginning of courses. We have identified analytical, search, design, creative components within the structure of ICT competence. Analytical component includes the ability to assess the feasibility of using certain websites for educational activities. Search component means the ability to choose the material for the implementation for educational activities; willingness and ability to use various search systems, databases for educational activities. Design component means the ability to design one's own educational electronic content and the ability to analyze its practical effectiveness. Creative component includes the ability to use digital educational resources created by the other colleagues, and the ability to create their own ones. The data obtained were summarized and converted to percentage. The empirical data were quantitatively processed and analyzed at a qualitative level. Dynamics of step-by-step development of ICT competence was established and the obtained data revealed in Table 1 and Table 2. 
Table 1. The results of the assessment of the level of ICT competence in the experimental and control groups before the experimental work

\begin{tabular}{|l|c|c|c|c|c|c|}
\hline \multirow{2}{*}{\begin{tabular}{c}
\multirow{2}{*}{$\begin{array}{c}\text { ICT } \\
\text { Competence }\end{array}$} \\
\cline { 2 - 7 }
\end{tabular}} & $\begin{array}{c}\text { Low } \\
\text { level, \% }\end{array}$ & $\begin{array}{c}\text { Middle level, } \\
\text { \% }\end{array}$ & High level, \% & Low level, \% & $\begin{array}{c}\text { Middle level, } \\
\text { \% }\end{array}$ & High level, \% \\
\hline Analytic component & 42,2 & 38,5 & 19,3 & 40,5 & 39,1 & 20,4 \\
\hline Search Component & 56,9 & 28,3 & 14,8 & 37,2 & 40,2 & 22,6 \\
\hline Design component & 43,5 & 32,8 & 23,7 & 42,9 & 29,7 & 27,4 \\
\hline Creative component & 58,1 & 29,3 & 12,6 & 43,6 & 35,2 & 21,2 \\
\hline
\end{tabular}

Table 2. The results of the assessment of the level of ICT competence in the experimental and control groups after the experimental work

\begin{tabular}{|l|c|c|c|c|c|c|}
\hline \multirow{2}{*}{\begin{tabular}{c}
\multirow{2}{*}{$\begin{array}{c}\text { ICT } \\
\text { Competence }\end{array}$} \\
\cline { 2 - 7 }
\end{tabular}} & $\begin{array}{c}\text { Low level, } \\
\text { \% }\end{array}$ & $\begin{array}{c}\text { Middle level, } \\
\text { \% }\end{array}$ & High level, \% & $\begin{array}{c}\text { Low level, } \\
\text { \% }\end{array}$ & $\begin{array}{c}\text { Middle } \\
\text { level, \% }\end{array}$ & $\begin{array}{c}\text { High } \\
\text { level, } \%\end{array}$ \\
\hline Analytic Component & 11,9 & 39,4 & 50,7 & 42,7 & 39,1 & 18,2 \\
\hline Search component & 7,1 & 27,3 & 65,7 & 35,2 & 43,5 & 21,3 \\
\hline Design component & 7,5 & 24,2 & 68,3 & 33,8 & 39,4 & 26,8 \\
\hline Creative component & 4,5 & 28,1 & 67,4 & 42,3 & 37,6 & 20,1 \\
\hline
\end{tabular}

Comparative analysis of the results of input and final diagnostics of the formation of ICT competence of teachers in the control and experimental groups showed a significant dynamic of the development of ICT competence in experimental groups, which indicates the effectiveness of the experimental work.

\section{Conclusion}

As practice shows, e-learning gives the opportunity to receive high-quality education to the people of any age and of different level of initial training, taking into account their individual characteristics and wishes. This form of education is the result of an objective process of informatization, absorbed the best features of adult education.

The modern concept of andragogy is built on ensuring the fact that everyone has open access to educational resources. Formation of the system of electronic education is facilitated by international integration processes unfolding in the sphere of education, as well as processes of informatization and technological development that lead to the pooling of resources of different level educational institutions implementing adult education programs into a unified information educational space that is open via Internet to the international educational community, other social institutions, every person. Creation of flexible variative system of andragogical education, combining traditions and innovations will ensure continuity and necessary degree of integration of all the levels of education within the framework of system of e-learning within the field of andragogy. 


\section{References}

[1] Abdulsalam, N., Condrasky, M., Bridges, W., Havice, P. (2017). The promise of andragogy and experimental learning to improve teaching of nutrition concepts to culinary arts students. Journal of Food Science Education, 16(2), 54-61. https://doi.org/10.1111/15414329.12107

[2] Appavoo, P., Sohoraye, M., Gungea, M., Armoogum, V. (2016). 'Webagogy' - the next milestone after pedagogy and andragogy? IEEE International Conference on Emerging Technologies and Innovative Business Practices for the Transformation of Societies, EmergiTech 2016, 317-322. https://doi.org/10.1109/emergitech.2016.7737359

[3] Azofeifa-Bolaños, J. B. (2017). Conceptual evolution and importance of andragogy towards the scope optimization of university academic rural development programs and projects. [Evolución conceptual e importancia de la andragogía para la optimización del alcance de los programas y proyectos académicos universitarios de desarrollo rural] Revista Electronica Educare, 21(1). https://doi.org/10.15359/ree.21-1.23

[4] Blackley, S., Sheffield, R. (2015). Digital andragogy: A richer blend of initial teacher education in the 21st century. Issues in Educational Research, 25(4), 397-414.

[5] Bubnov Y. A., Gaidar K. M., Fedorov V.A., Berezhnaya I.F., Galustyan O.V. (2018). Organization of the Training Process Based on Modular and Rating Technology at Higher Educational Institution. Revista Espacios, Vol. 39(N 25). P.25.

[6] Buhl, M., Andreasen, L. B. (2018). Learning potentials and educational challenges of massive open online courses (MOOCs) in lifelong learning. International Review of Education, 64(2), 151-160. https://doi.org/10.1007/s11159-018-9716-Z

[7] Dhirathiti, N. S., Pichitpatja, P. (2018). Characteristics and differences of lifelong learning policy implementation for the elderly in Thailand. Educational Research for Policy and Practice, 17(1), 53-68. https://doi.org/10.1007/s10671-017-9219-x

[8] Flahive, T. (2015). Andragogy applications in ADCO leadership programmes. Society of Petroleum Engineers - Abu Dhabi International Petroleum Exhibition and Conference, ADIPEC 2015. https://doi.org/10.2118/177535-ms

[9] Fornaciari, C. J., Lund Dean, K. (2014). The 21st-century syllabus: From pedagogy to andragogy. Journal of Management Education, 38(5), 701-723. https://doi.org/10.11 77/1052562913504763

[10] Gaikwad, S. S., Bharathi, S. V. (2018). An exploratory study on the application of multiple intelligences to MBA andragogy with particular reference to ERP-controlling configuration course. International Journal of Information and Communication Technology Education, 14(1), 58-72. https://doi.org/10.4018/ijicte.2018010105

[11] Galustyan, O.V. Berezhnaya, I.F., Beloshitsky, A.V. (2017). Professional and Career Development of Teachers. Sodobna Pedagogika / Journal of Contemporary Educational Studies, 68(№4), pp.158-172. Retrieved from http://www.sodobna-pedagogika.net/wpcontent/uploads/2017/12/8-galustyan_ang-2017-4.pdf. https://doi.org/10.18411/a-2017$\underline{023}$

[12] Galustyan, O.V., Lazukin, V.F., Petelin, A.S., Ostapenko, V.S. (2018). Diagnostic Activity of Teachers at High School. Revista Espacios, Vol. 39(N 10). Retrieved from http http://www.revistaespacios.com/a18v39n10/18391024.html

[13] Ghazalan, M. S., Abd Samad, N., Ab Halim, F., Hamidon, N. I., Ahmad Hariri, T. I. A. (2018). Level readiness participant of lifelong learning (LLL) program venture into entrepreneurship. MATEC Web of Conferences, 150 . https://doi.org/10.1 $\underline{051 / \mathrm{matec} o n f} / 201815005029$ 
[14] Hermann-Shores, P. (2017). Enabling pedagogy and andragogy for 21st-century sign language users and learners. American Annals of the Deaf, 162(4), 360-364. https://doi.org/10.1353/aad.2017.0033

[15] Jali, S. K., Arnab, S. (2016). The andragogical perspectives of older people's interaction with digital game technologies: Gameplay on gesture and touch-based platforms. Proceedings of the European Conference on Games-Based Learning, 2016-January 319-326.

[16] Knowles, M. (1970). The Modern Practice of Adult Education: From Pedagogy to Andragogy. Retrieved from https://www.nationalcollege.org.uk/cm-andragogy.pdf

[17] Komarova, E.P., Fetisov, A. S., Larina, T.V., Galustyan, O.V. (2017). The Development of Physical Training Culture of a Personality. Revista Espacios, Vol. 38(N 50). Retrieved from http://www.revistaespacios.com/a17v38n50/17385028.html

[18] Kravchenko E.V., Galustyan O.V, Kovtunenko L.V., Kolosova L.A. (2018). Pedagogical Practice of Students. Revista Espacios, Vol. 39 (N 17). Retrieved from http://www.revistaespacios.com/a18v39n17/18391731.html

[19] Lang, C., Craig, A., Casey, G. (2017). A pedagogy for outreach activities in ICT: Promoting peer to peer learning, creativity and experimentation. British Journal of Educational Technology, 48(6), 1491-1501. https://doi.org/10.1111/bjet.12501

[20] Li, S. (2018). Application of virtual environment in the teaching of basketball tactics. International Journal of Emerging Technologies in Learning, 13(7), 174-186. https://doi.org/10.3991/ijet.v13i07.8808

[21] Liu, X., Zhang, J. (2018). Application of computer distance education in practical English writing teaching. International Journal of Emerging Technologies in Learning, 13(4), 7182. https://doi.org/10.3991/ijet.v13i04.8471

[22] Moore, M. G. (2016). Flipped classrooms, study centers andragogy and independent learning. American Journal of Distance Education, 30(2), 65-67. https://doi.org/10.1 $\underline{080 / 08923647.2016 .1168637}$

[23] Ramnath, S. (2016). Applying the whole-part-whole andragogy to computing. Annual Conference on Innovation and Technology in Computer Science Education, ITiCSE, 1113-July-2016 372. https://doi.org/10.1145/2899415.2925497

[24] Sharifi, M., Soleimani, H., Jafarigohar, M. (2017). E-portfolio evaluation and vocabulary learning: Moving from pedagogy to andragogy. British Journal of Educational Technology, 48(6), 1441-1450. https://doi.org/10.1111/bjet.12479

[25] Shen, Y. (2018). Design of digital network shared learning platform based on SCORM standard. International Journal of Emerging Technologies in Learning, 13(7), 214-227. https://doi.org/10.3991/ijet.v13i07.8602

[26] Watts, K. A. (2018). Tools and principles for effective online library instruction: Andragogy and undergraduates. Journal of Library and Information Services in Distance Learning, 1-7. https://doi.org/10.1080/1533290x.2018.1428712

[27] Winarno, S., Muthu, K. S., \& Ling, L. S. (2018). Impacts of m-DPBL approach towards computer networks teaching and learning process. International Journal of Emerging Technologies in Learning, 13(3), 207-215. https://doi.org/10.3991/ijet.v13i03.7944

[28] Xu, Y. (2018). Construction of a multiple English teaching mode based on cloud technology. International Journal of Emerging Technologies in Learning, 13(8), 239-253. https://doi.org/10.3991/ijet.v13i08.9054

[29] Zhang, Y., \& Jiang, W. (2018). Score prediction model of MOOCs learners based on neural network. International Journal of Emerging Technologies in Learning, 13(10), 171-182. https://doi.org/10.3991/ijet.v13i10.9461 


\section{Authors}

Olga V. Galustyan is Professor of the Department of Education and Pedagogical Sciences of Southern Federal University, Rostov-on-Don, Russia.

Yana V. Borovikova is Associate Professor of the Department of Social Work, Sociology and Psychological and Pedagogical Disciplines of Institute of Social Education, Voronezh, Russia.

Nadezhda P. Polivaeva is Professor of the Department of Humanitarian and Socio-Economic Disciplines of Voronezh Institute of the Federal Penitentiary Service of Russia, Russia.

Bakhtiyor R. Kodirov is Professor of the Department of Natural Sciences, Voronezh State Technical University, Branch in Borisoglebsk, Russia.

Galina P. Zhirkova is Associate Professor of the Department of Social and Human Sciences of St. Petersburg National Research University of Information Technology, Mechanics and Optics, Russia.

Article submitted 2018-12-18. Resubmitted 2019-01-28. Final acceptance 2019-02-05. Final version published as submitted by the authors. 